\title{
HIF-1a downregulation and apoptosis in hypoxic prostate tumor cells infected with oncolytic Mammalian Orthoreovirus
}

\author{
Pooja Gupta-Saraf ${ }^{1,2}$ and Cathy L. Miller ${ }^{1,2,3}$ \\ ${ }^{1}$ Department of Veterinary Microbiology and Preventive Medicine, Iowa State University, Ames, IA \\ 2 Interdepartmental Genetics Program, Iowa State University, Ames, IA \\ ${ }^{3}$ College of Veterinary Medicine, Iowa State University, Ames, IA \\ Correspondence to: Cathy L. Miller, email: clm@iastate.edu
}

Keywords: HIF-1a, hypoxia, prostate cancer, Reovirus, viral oncolysis

Received: January 13,2014 Accepted: January 29, 2014

Published: January 31, 2014

This is an open-access article distributed under the terms of the Creative Commons Attribution License, which permits unrestricted use, distribution, and reproduction in any medium, provided the original author and source are credited.

\section{ABSTRACT:}

Hypoxia has emerged as one of the most important drivers of tumor aggression, metastasis, and poor clinical outcome in many cancers. In prostate cancer (PCa), hypoxia has been strongly correlated to biochemical failure and local recurrence. However, current PCa treatment options do not address hypoxic cells highlighting a critical gap in existing therapies and the need for development of therapies that target hypoxic prostate tumor cells. Mammalian orthoreovirus (MRV) is an oncolytic virus that targets tumor cells over normal cells which has been shown to be safe and effective against many cancers in vitro, in animal models, and in human clinical trials. We found that MRV infects and replicates in hypoxic prostate tumor cells to levels comparable to normoxic cells leading to apoptosis and cell death. In addition, the regulatory subunit (HIF-1a) of the master transcriptional regulator of hypoxia, HIF-1, was significantly downregulated in infected cells. HIF-1a downregulation was found to occur via ubiquitin-dependent proteasome-mediated degradation and translational inhibition. Virus-mediated HIF-1a degradation required the HIF-1a PAS domain and expression of the receptor for activated kinase C (RACK1) protein. These data provide evidence that MRV may be a viable therapeutic option for targeting hypoxic cells and HIF-1a in PCa.

\section{INTRODUCTION}

Disease progression and mortality in cancer patients is often correlated with the presence of chronic or transient hypoxic microregions within tumors [1-3]. Hypoxia induced changes can lead to tumor propagation through the selection of hypoxia-adapted mutant cells. Cells develop hypoxia adaptation through the upregulation of genes encoding proteins that promote proliferation, apoptosis resistance, and angiogenesis [4, 5]. Upregulation of these genes in turn leads to increased tumor invasion and metastasis, resulting in disease progression and poor clinical outcome [6, 7]. Moreover, hypoxic tumor cells are often resistant to chemotherapy and radiotherapy, posing further challenges to the development of treatments that will lead to a complete cancer cure $[8,9]$.

Prostate cancer (PCa) is the second leading cause of cancer death in men in the United States [10]. Therapies, in the form of surgical removal and radiotherapy, have undesired side effects such as impotency and urinary incontinence [11]. Hormone therapy, consisting of surgical or chemical deprivation of androgen, is an additional treatment option for PCa patients. However, most prostate tumors develop androgen resistance within one to three years of therapy onset and resume growth. Detection of molecular markers of hypoxia in prostate tumors has been linked to progression, poor prognosis, low survival rate and early biochemical relapse $[12,13]$. Considering that prostate tumors extract benefit from poor oxygenation for survival and metastasis, there is a crucial need for the development of therapeutics targeting hypoxic PCa cells.

The upregulation of proteins involved in adaptation and survival in the hypoxic environment is controlled by the transcription factor, hypoxia inducible factor 1 (HIF1). HIF-1 is a heterodimer of two helix-loop-helix PerARNT-Sim proteins, HIF- $1 \alpha$ and HIF- $1 \beta$. When HIF- $1 \alpha$ 
and HIF-1 $\beta$ are present, they form a dimer, translocate to the nucleus, and bind to canonical DNA sequences termed hypoxia response elements (HREs) in the promoter or enhancer regions of target genes [14]. The formation of HIF-1 is dependent on the availability of HIF-1 $\alpha$, which is tightly regulated post-translationally via oxygendependent and -independent degradation pathways. Under normoxic conditions, HIF-1 $\alpha$ is hydroxylated by prolyl hydroxylase 2 (PHD2) at proline residues 402 and 564 [15, 16]. This leads to binding of von Hippel-Lindau (pVHL) protein to the HIF-1 $\alpha$ oxygen dependent degradation (ODD) domain. pVHL recruits an E3 ubiquitin-protein ligase complex to HIF-1 $\alpha$, resulting in ubiquitination and degradation of HIF- $1 \alpha$ by the $26 \mathrm{~S}$ proteasome [17-19]. Under hypoxic conditions the action of PHD2 is inhibited and HIF-1 $\alpha$ is stabilized. An oxygen-independent pathway for HIF-1 $\alpha$ degradation is regulated by the receptor for activated $\mathrm{C}$ kinase (RACK1) protein, which competes with heat shock protein 90 (HSP90) for binding to the HIF-1 $\alpha$ PAS domain [20]. Binding of HSP90 leads to stabilization of HIF- $1 \alpha$ and binding of RACK 1 to HIF- $1 \alpha$ leads to its ubiquitination and proteasome mediated degradation by an E3 ubiquitin ligase complex [20].

Mammalian orthoreovirus (MRV) is a clinically benign, double stranded RNA family Reoviridae member that is not associated with major pathogenicity in humans or other animals. MRV is an oncolytic virus that preferentially replicates in tumor cells over normal cells [21]. Successful demonstration of MRV oncolytic activity against numerous cancer types in animal models [22-24] led to its development and clinical testing as a cancer therapy in a number of Phase I/II/III human clinical trials. It has emerged as a safe and effective therapy for a number of cancer types leading to disease stabilization and tumor regression in many patients [25-28]. With regards to $\mathrm{PCa}$, MRV specifically replicates in and kills PCa cells in vitro, in an in vivo animal model, and in human patients [29, 30].

Little is known about the impact of MRV infection on hypoxic tumor cells. One previous study suggested that MRV infection leads to decreased levels of HIF-1 $\alpha$ in hypoxic lung, colon, and renal tumor cells in a manner dependent on proteasome inhibition but independent of VHL expression. This study also suggested that MRV protein expression was inhibited in VHL-/- cells that constitutively express HIF-1 $\alpha$ and that MRV infection induced cell death through the activation of caspase 8 and apoptosis [31]. In contrast, another study showed that MRV infection stabilized HIF-1 $\alpha$ and induced apoptosis in a caspase independent mechanism in human glioblastoma cell lines [32]. These studies clearly indicate that the effects of hypoxia on MRV infection and the effects of MRV on the hypoxic response and cell death in tumor cells growing under hypoxic conditions is cell type specific and thus findings from one tumor type cannot be applied to another. A comprehensive investigation of MRV replication under hypoxic conditions and the mechanisms involved in MRV-induced HIF-1 $\alpha$ regulation was not done in either of these prior studies. The objectives for this study were to examine MRV replication, impact on the hypoxic response, and induction of tumor cell death of three prostate tumor cell lines that vary in both androgen sensitivity and metastatic potential grown under normoxic and hypoxic conditions. We found that MRV readily replicates in and kills prostate tumor cells growing in hypoxic conditions, and further, that HIF-1 $\alpha$ protein levels and activity are downregulated in MRV infected prostate tumor cells. We additionally provide evidence that in PCa cells, MRV-induced HIF-1 $\alpha$ degradation requires the HIF-1 $\alpha$ PAS domain, and is inhibited following siRNA knockdown of RACK1, suggesting that MRV induces HIF-1 $\alpha$ degradation through the RACK1 pathway. These findings represent an important step in the characterization of MRV oncolytic treatment as a therapy for killing hypoxia adapted prostate tumor cells.

\section{RESULTS}

\section{MRV is translationally active and replicates in hypoxic tumor cells.}

Hypoxia-induced shutoff of protein synthesis negatively impacts the ability of some oncolytic viruses to replicate in tumor cells growing in hypoxic environments $[33,34]$. Because MRV mRNAs escape host translational shutoff induced by infection, [35], we hypothesized that MRV may replicate in prostate tumor cells growing in a hypoxic environment. To test this hypothesis, we examined MRV infection in normoxic and hypoxic prostate tumor cell lines. We examined three cell lines that represent androgen-resistant, moderate metastatic (DU145), androgen-resistant, high metastatic (PC-3), and androgen-sensitive, low metastatic ( $\mathrm{LNCaP})$ prostate tumor cells. Each cell line was incubated in normoxic or hypoxic conditions for $4 \mathrm{~h}$, at which time induction of the hypoxic response was evident by strong upregulation of HIF-1 $\alpha$ (data not shown). In addition to growth in hypoxic conditions, independent samples were treated with cobalt chloride $\left(\mathrm{CoCl}_{2}\right)$, which mimics hypoxia in the cell by inhibiting PHD2 hydroxylation of HIF-1 $\alpha$ [36]. Normoxic, hypoxic, or $\mathrm{CoCl}_{2}$-treated cells were then mock infected or infected with MRV and incubated for an additional 24 or $48 \mathrm{~h}$ under normoxic or hypoxic conditions. Following incubation, cells were harvested in protein loading buffer, and immunoblots against virus non-structural protein $\mu \mathrm{NS}$ were performed to examine MRV protein synthesis. We observed that virus protein translation was not substantially changed by growth under hypoxic relative to normoxic conditions, suggesting the virus was able to enter and initiate infection in hypoxic prostate tumor cells (Fig. 1A). To examine the impact of hypoxia on viral 
replication, we infected each cell line with MRV under normoxic or hypoxic conditions. Samples were harvested at $6 \mathrm{~h}$ intervals and plaque assays were performed to measure virus titers. We found that virus growth was not significantly different in hypoxic relative to normoxic conditions in any of the tested cell lines (Fig. 1B). Thus we established that MRV productively enters, translates protein, and replicates in diverse hypoxic prostate tumor cell lines in a manner indistinguishable from that measured in normoxic tumor cells. These data suggest that hypoxic conditions do not interfere with successful MRV infection in prostate tumor cells.

\section{MRV infection results in diminished HIF-1a protein levels and activity in hypoxic prostate tumor cells.}

In separate prior studies, MRV infection was found to induce an increase in HIF- $1 \alpha$ proteasome-mediated degradation in lung-, renal-, and colon-derived cancer cells (Cho et al., 2010), but to induce a decrease in HIF-1 $\alpha$ degradation in brain-derived tumor cells [32], suggesting MRV infection has variable effects on the cellular hypoxic response depending on tumor type. To determine if HIF-1 $\alpha$ expression was altered by MRV infection in hypoxic prostate tumor cells, we first performed immunofluorescence assays to examine HIF-1 $\alpha$ expression on an individual cell level. Normoxic or hypoxic DU145, PC-3, and LnCaP cells were mock infected or infected with MRV and further incubated in normoxic or hypoxic conditions. At 24 h p.i., cells were fixed and stained with antibodies against HIF- $1 \alpha$ and the MRV non-structural protein $\mu$ NS. In agreement with our data suggesting hypoxia does not negatively impact MRV replication (Fig. 1), viral factories, which are key players in MRV replication and assembly, were not qualitatively different in size or number in infected cells grown in hypoxic and normoxic conditions (Fig. 2A). However, while uninfected hypoxic cells showed an increase in nuclear HIF-1 $\alpha$ staining relative to normoxic cells, infected hypoxic cells did not show a similar increase in HIF-1 $\alpha$ staining in response to hypoxic incubation, suggesting MRV infection may prevent accumulation of HIF-1 $\alpha$ protein under these conditions (Fig. 2A). We next performed immunoblot assays against $\mathrm{HIF}-1 \alpha$ in normoxic, hypoxic, or $\mathrm{CoCl}_{2}$ treated mock or MRV infected DU145, PC-3, and LNCaP cells. As expected, there was no accumulation of HIF-1 $\alpha$ in mock- or MRV-infected samples grown in normoxic conditions (Fig. 2B, lanes 1 and 2 in each cell line), but abundant HIF-1 $\alpha$ protein in hypoxic and $\mathrm{CoCl}_{2}$ treated mock-infected samples (Fig. 2B, lanes 3 and 5 in each cell line). Strikingly, HIF-1 $\alpha$ protein levels did not accumulate in MRV-infected hypoxic or $\mathrm{CoCl}_{2}$ treated cells (Fig. $2 \mathrm{~B}$, lanes 4 and 6 in each cell line) further suggesting MRV infection results in a strong downregulation of HIF- $1 \alpha$ protein accumulation. To extend these findings, we examined whether HIF-1 $\alpha$ protein activity was similarly diminished by MRV infection by measuring transcription from a HIF-1 $\alpha$-dependent firefly luciferase plasmid (pHRE-Luc) transfected into mock- and MRVinfected DU145 cells grown in normoxic and hypoxic conditions. These assays showed an expected increase in

$\boldsymbol{A}$
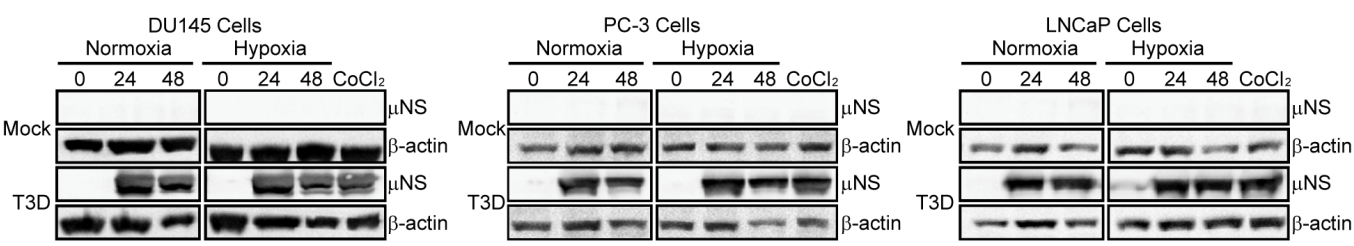

B
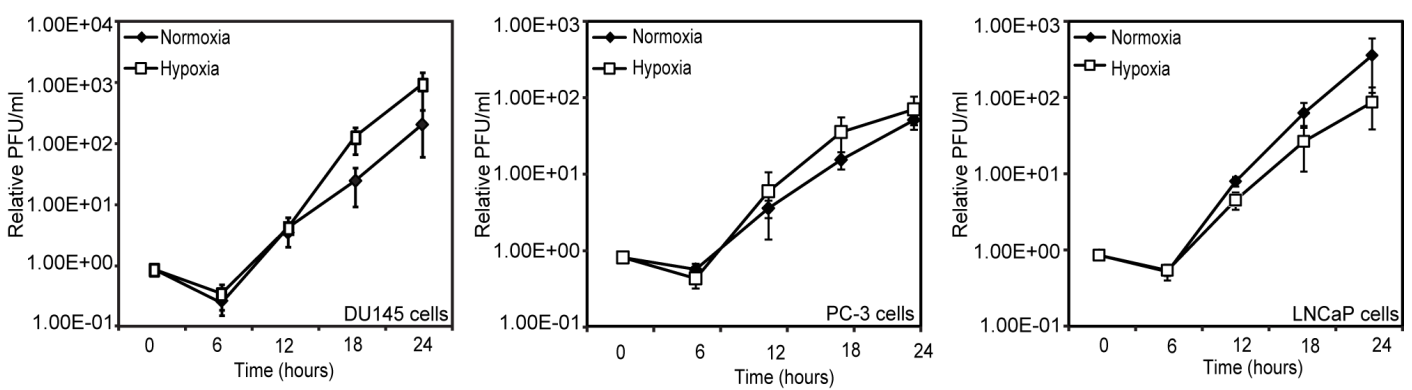

Figure 1: Hypoxia does not interfere with MRV translation or replication in prostate tumor cells. Normoxic or hypoxic DU145, PC-3 and LNCaP prostate tumor cells were mock-infected or infected with MRV T3D and further incubated under normoxic or hypoxic conditions. $\mathrm{CoCl}_{2}$ was added to cells where indicated at $4 \mathrm{~h}$ prior to infection. A) At indicated times, cells were harvested and proteins were separated on SDS-PAGE and transferred to nitrocellulose. Blots were immunostained with rabbit $\alpha$ - $\mu$ NS polyclonal antiserum or rabbit $\beta$-actin polyclonal antibodies followed by AP-conjugated goat $\alpha$-rabbit IgG secondary antibodies. B) At $0,6,12,18$, and $24 \mathrm{~h}$ p.i., cells were harvested and subjected to three freeze/thaw cycles. Standard virus plaque assays on L929 cells were performed on cell lysates to determine virus titer (PFU). Mean of the relative PFU/ml from three independent experiments is plotted and the error bars represent the standard deviation $(\mathrm{SD})$. 
HIF-1 $\alpha$ activity as measured by luciferase expression in uninfected hypoxic relative to normoxic cells. However, HIF- $1 \alpha$ activity was strongly diminished in MRV-infected compared to mock-infected hypoxic cells (Fig. 2C), further supporting the conclusion that MRV infection results in diminished levels of active HIF-1 $\alpha$ protein in hypoxic prostate tumor cells. To rule out the possibility that MRV infection was interfering with HIF-1 $\alpha$ mRNA levels, we performed quantitative real time PCR on RNA isolated from mock- and MRV-infected DU145 cells grown in normoxic and hypoxic environments. As shown in Fig. 2D, there was no significant difference in HIF-1 $\alpha$ mRNA levels in these samples. Altogether, these data strongly demonstrate that MRV infection interferes with accumulation of active HIF- $1 \alpha$ protein in hypoxic prostate tumor cells.

\section{MRV induced downregulation of HIF-1 $\alpha$ occurs via ubiquitin-dependent proteasome-mediated degradation and translational inhibition.}

In uninfected cells under normoxic conditions, HIF-1 $\alpha$ protein is rapidly targeted to the proteasome for degradation [19]. Thus we hypothesized that MRV induced HIF-1 $\alpha$ downregulation in prostate tumor cells may require a functional proteasome. To test this, we examined HIF-1 $\alpha$ protein accumulation in the absence and presence of proteasome inhibitor, MG132. Mock and MRV infected DU145, PC-3, and LnCaP cells were grown in normoxic or hypoxic conditions and treated with MG132 for $4 \mathrm{~h}$ at either 8 or $20 \mathrm{~h}$ p.i., at which point cells were harvested and HIF-1 $\alpha$ levels were measured by
$\boldsymbol{A}$

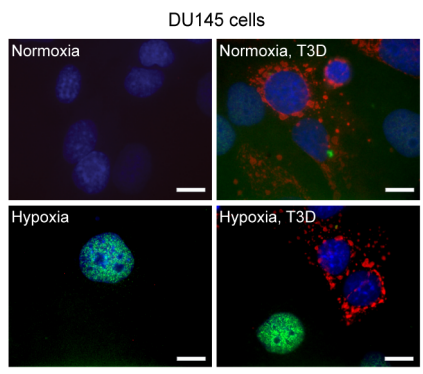

B

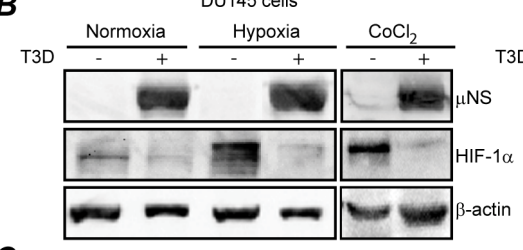

C

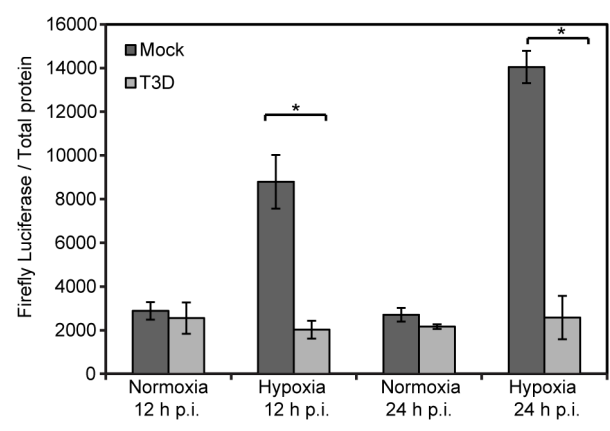

PC-3 cells

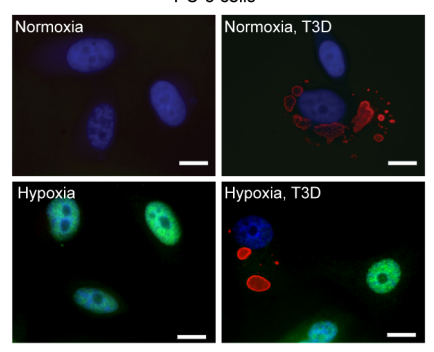

PC-3 cells

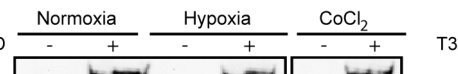

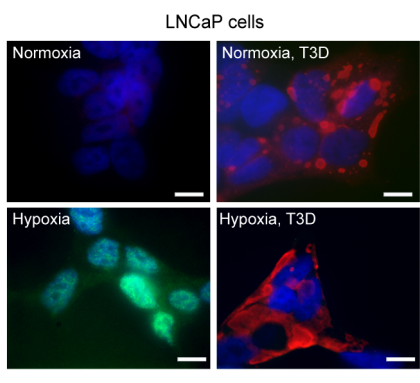

LNCaP cells

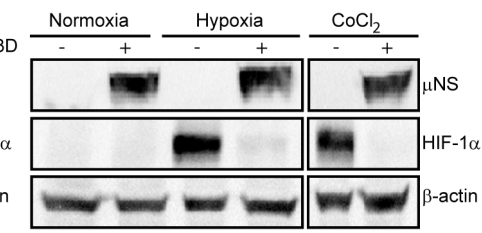

$\boldsymbol{D}$

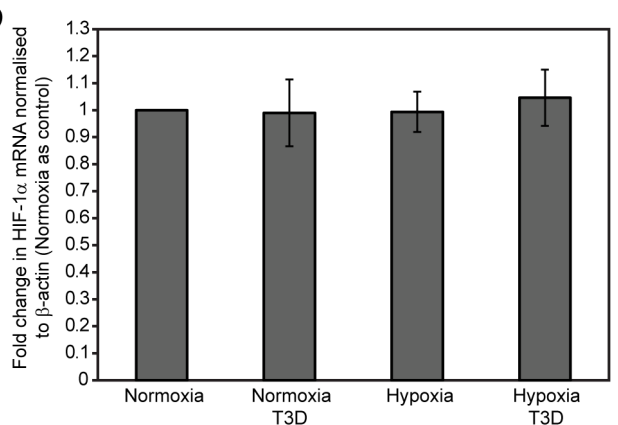

Figure 2: MRV infected hypoxic prostate tumor cells contain diminished HIF-1 $\alpha$ protein levels. A) Normoxic or hypoxic DU145, PC3, and LNCaP cells were mock-infected or infected with MRV T3D and further incubated under normoxic or hypoxic conditions. 24 h p.i., cells were fixed, permeabilized, and immunostained with rabbit $\mu$ NS antiserum (red) and mouse HIF-1 $\alpha$ antibodies (green) followed by donkey $\alpha$-rabbit Alexa 594- and donkey $\alpha$-mouse Alexa 488-conjugated secondary antibodies. A merged image with DAPI is shown. Bar, $10 \mu \mathrm{m}$. B) Normoxic or hypoxic DU145, PC3 and LNCaP cells were mock-infected or infected with MRV T3D and further incubated under normoxic or hypoxic conditions. $4 \mathrm{~h}$ prior to infection, $\mathrm{CoCl}_{2}$ was added to cells where indicated. At $24 \mathrm{~h}$ p.i., cells were harvested and proteins were separated on SDS-PAGE and transferred to nitrocellulose. Blots were immunostained with rabbit $\alpha-\mu$ NS antiserum, mouse $\alpha$-HIF- $1 \alpha$ antibodies, or rabbit $\alpha-\beta$-actin antibodies followed by AP-conjugated goat $\alpha$-rabbit or mouse secondary antibodies . C) DU145 cells were transfected with pHRE-Luc and incubated under normoxic or hypoxic conditions. $24 \mathrm{~h}$ post-transfection, cells were mock-infected or infected with MRV T3D and further incubated in normoxic or hypoxic conditions. At 12 or 24 h p.i., luciferase activity and total protein were measured. Relative amounts of luciferase per total protein are shown. Error bars represent SD of three independent experiments. Statistically significant differences $(\mathrm{p}<0.05)$ are marked with '*'. D) DU145 cells were mock-infected or infected with MRV T3D and incubated under normoxic or hypoxic conditions. 24 h p.i., total RNA was isolated and measured using qPCR. Data from three independent experiments are represented as mean \pm standard error of the mean (SEM). 
immunoblot. MRV infection again resulted in decreased HIF-1 $\alpha$ levels in hypoxic tumor cells in the absence of MG132 at both times p.i. in all cell lines (Fig 3A). Addition of MG132 to the infected samples from 8-12 h p.i., was able to rescue HIF-1 $\alpha$ to levels similar to those seen in uninfected cells (Fig. 3A); suggesting that MRV infection induces proteasome-mediated degradation of HIF- $1 \alpha$ in hypoxic prostate tumor cells at early times p.i.

Surprisingly, the addition of MG132 at later times in infection was unable to rescue HIF-1 $\alpha$, suggesting that, in addition to proteasome-mediated degradation, a second mode of inhibition of HIF-1 $\alpha$ protein accumulation was occurring in MRV infected cells. Because there was no difference in HIF-1 $\alpha$ mRNA levels in uninfected and infected cells at this time p.i., (Fig. 2D), we hypothesized that MRV may inhibit HIF-1 $\alpha$ mRNA translation. To examine this, we directly measured the levels of HIF- $1 \alpha$ protein translated at early and late times p.i. Mock or MRV infected DU145 cells were incubated in normoxic and hypoxic conditions, and from 6-12 and 18-24 h p.i., the methionine analog, L-AHA was added to the cells to label proteins being translated during the incubation period. MG132 was also added to some samples to prevent proteasome-mediated degradation of the protein that was translated during the labeling time frame. At 12 and 24 $\mathrm{h}$ respectively, cells were harvested and L-AHA labeled
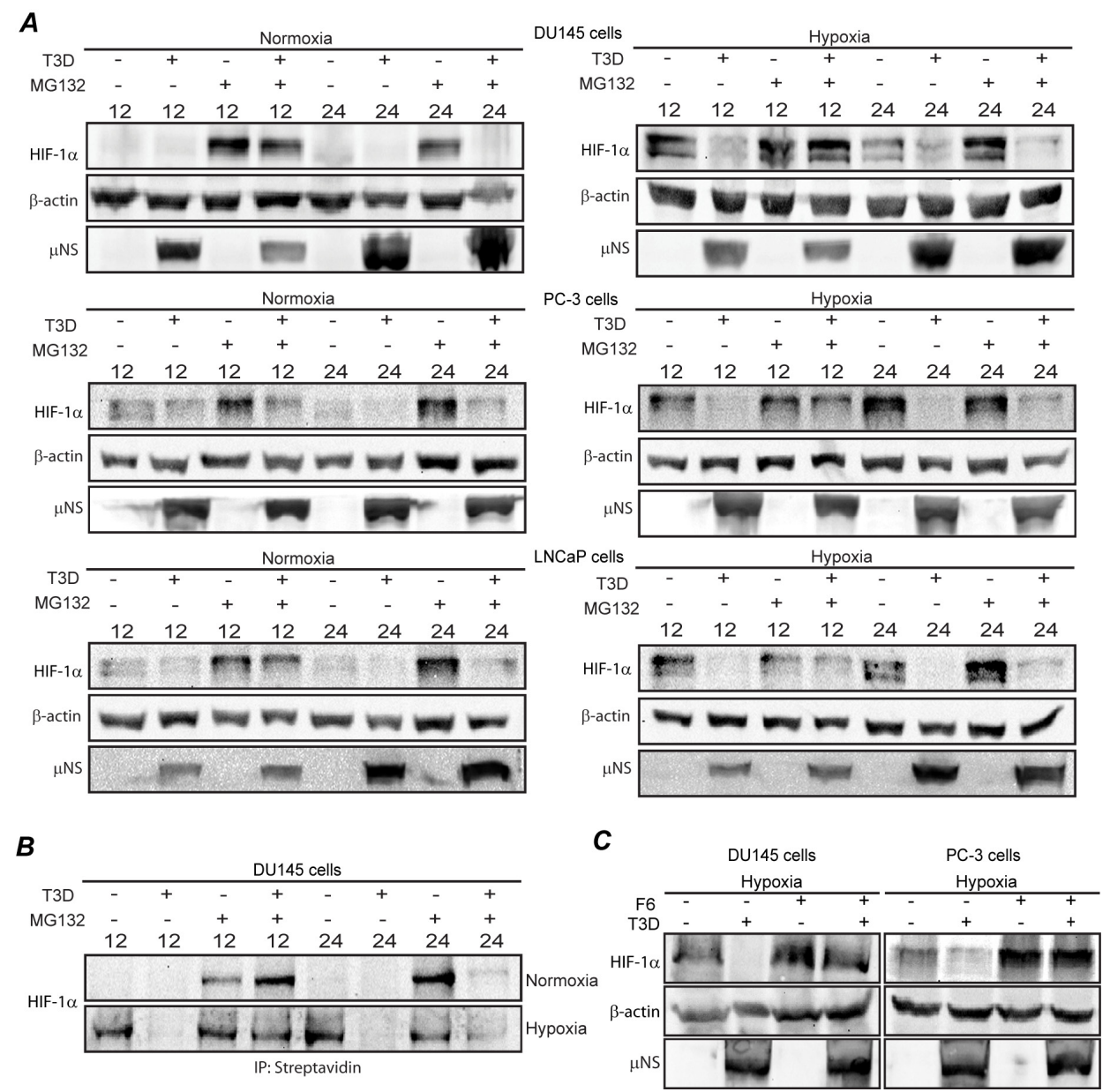

Figure 3: MRV induced downregulation of HIF-1 $\alpha$ occurs via ubiquitin-dependent proteasome-mediated degradation and translational inhibition. A) Normoxic or hypoxic DU145, PC3 and LNCaP cells were mock-infected or infected with MRV T3D and further incubated under normoxic or hypoxic conditions. MG132 was added to cells at 8 or $20 \mathrm{~h} \mathrm{p.i.} \mathrm{At} 4 \mathrm{~h}$ following MG132 addition, cells were harvested and proteins were separated on SDS-PAGE and transferred to nitrocellulose. Blots were immunostained with rabbit $\alpha-\mu$ NS antiserum, mouse $\alpha$-HIF- $1 \alpha$ antibodies, or rabbit $\alpha-\beta$-actin antibodies followed by AP-conjugated goat $\alpha$-rabbit or mouse secondary antibodies. B) Normoxic or hypoxic DU145 cells were mock-infected or infected with MRV T3D and further incubated under normoxic or hypoxic conditions. L-AHA was added to the cells in methionine deficient media at 6 and $18 \mathrm{~h}$ p.i. Cells were harvested at 12 and $24 \mathrm{~h}$ p.i., and conjugated to biotin-alkyne via a Click-It reaction. Proteins were precipitated using streptavidin coated magnetic beads, separated on SDS-PAGE, transferred to nitrocellulose and immunostained with mouse $\alpha$-HIF-1 $\alpha$ antibodies followed by AP-conjugated goat $\alpha$ mouse secondary antibodies. C) Normoxic or hypoxic DU145 and PC3 cells were mock-infected or infected with MRV T3D and further incubated under normoxic or hypoxic conditions. At $6 \mathrm{~h}$ p.i. F6 was added and cells were incubated an additional $6 \mathrm{~h}$, at which point cells were harvested and proteins separated on SDS-PAGE and transferred to nitrocellulose. Blots were immunostained with mouse $\alpha$-HIF-1 $\alpha$ antibodies, rabbit $\alpha-\beta$-actin antibodies and rabbit $\alpha-\mu \mathrm{NS}$ antiserum followed by AP-conjugated goat $\alpha$-rabbit or mouse secondary antibodies 
proteins were conjugated with biotin, and precipitated with streptavidin-conjugated beads, followed by HIF-1 $\alpha$ immunoblot (Fig. 3B). In agreement with Fig. 3A, MG132 treatment rescued the HIF-1 $\alpha$ synthesized during the 6-12 $\mathrm{h}$ p.i. labeling period, confirming that MRV infection induced proteasome-mediated degradation of HIF-1 $\alpha$ in hypoxic cells during this time. However, MG132 treatment had little impact on HIF-1 $\alpha$ accumulation during the $18-24 \mathrm{~h}$ p.i. labeling time, confirming that HIF-1 $\alpha$ was not being synthesized during this period, and that at later times during MRV infection, HIF-1 $\alpha$ protein translation is inhibited. Taken together, these data indicate that HIF-1 $\alpha$ down-regulation in MRV infected hypoxic prostate tumor cells occurs via both proteasome-mediated degradation and inhibition of HIF-1 $\alpha$ mRNA translation.

HIF- $1 \alpha$ is targeted to the proteasome through both ubiquitin-dependent and -independent mechanisms [37]. To investigate whether MRV induced degradation of HIF$1 \alpha$ occurs through a ubiquitin-dependent or -independent pathway, we utilized a deubiquitinating enzyme inhibitor [NSC632839 hydrochloride (F6)] [38], which prevents removal of ubiquitin chains from polyubiquitinated proteins, inhibiting ubiquitin-dependent, proteasomemediated degradation. DU145 and PC-3 cells were mock or MRV infected and treated or not with F6 from 8-12 h p.i., at which point proteins were harvested, and HIF-1 $\alpha$ levels were analyzed by immunoblot analysis. The addition of F6 rescued HIF-1 $\alpha$ from MRV-induced degradation (Fig. 3C) implicating a ubiquitin-dependent pathway in MRV-induced HIF-1 $\alpha$ proteasome-mediated degradation.

\section{The PAS domains of HIF-1 $\alpha$ are required for MRV-induced degradation.}

Several regions within HIF-1 $\alpha$ have been identified that are involved in proteasome-mediated degradation. Two of these regions (aa 380-417 and aa 556-572) contain prolines that when hydroxylated by PHD proteins results in recognition by the VHL E3 ubiquitin ligase and targeting of HIF-1 $\alpha$ to the proteasome. Another region includes the PAS A and B domains (aa 85-158 and aa 228-
298), which are competitively bound by either HSP90 or RACK1 proteins, which promote stability or degradation of HIF- $1 \alpha$, respectively. To determine if the MRV induced degradation of HIF-1 $\alpha$ could be mapped to either of these regions within the HIF-1 $\alpha$ protein, we utilized HA-tagged HIF-1 $\alpha$ encoding plasmids that expressed wild-type HIF$1 \alpha$ (pHA-HIF-1 $\alpha$ ), PHD hydroxylation mutant HIF- $1 \alpha$ (pHA-HIF- $1 \alpha$ P402A/P564A) or a PAS A and B domain deletion mutant HIF-1 $\alpha$ (pHA-HIF-1 $\alpha \Delta$ PAS). PC-3 cells were transfected with wildtype or mutant plasmids, and at $24 \mathrm{~h}$ post-transfection, cells were mock or MRV infected, and incubated under normoxic and hypoxic conditions. At $12 \mathrm{~h}$ p.i., cells were harvested, and accumulation of wild-type and mutant HA-HIF-1 $\alpha$ proteins was determined by immunoblotting. In these experiments, MRV infection caused the downregulation of both wild-type HA-HIF-1 $\alpha$ and mutant HA-HIF-1 $\alpha$ P402A/P564A relative to mock infected cells. However the HA-HIF-1 $\alpha \Delta \mathrm{PAS}$ protein accumulated to similar levels in both mock and MRV infected cells (Fig. 4), suggesting that the PAS domains of HIF- $1 \alpha$ are necessary for MRV infection induced degradation of HIF-1 $\alpha$.

\section{siRNA knockdown of RACK1 prevents MRV- induced degradation of HIF-1 $\alpha$.}

Since MRV infection induces degradation of HIF$1 \alpha$ under hypoxic conditions, and additionally induces the degradation of the VHL binding mutant HA-HIF$1 \alpha(\mathrm{P} 402 \mathrm{~A} / \mathrm{P} 564 \mathrm{~A})$, it is unlikely that virus-induced degradation of HIF- $1 \alpha$ occurs via the VHL-dependent pathway. However, deletion of the PAS domains of HIF$1 \alpha$, which are necessary for RACK 1 binding, prevents MRV-induced HIF-1 $\alpha$ degradation (Fig. 4), suggesting that MRV induced degradation of HIF- $1 \alpha$ may occur through a RACK1 dependent pathway. To examine this possibility, we utilized two siRNAs (siRNA 1 and siRNA 2) specific for different regions of the RACK1 mRNA to knockdown RACK1 expression in mock and MRV infected normoxic and hypoxic tumor cells. Quantification of RACK1 levels following knockdown confirmed that cells transfected with RACK 1 siRNA 1 or 2 contained on average $60 \%$
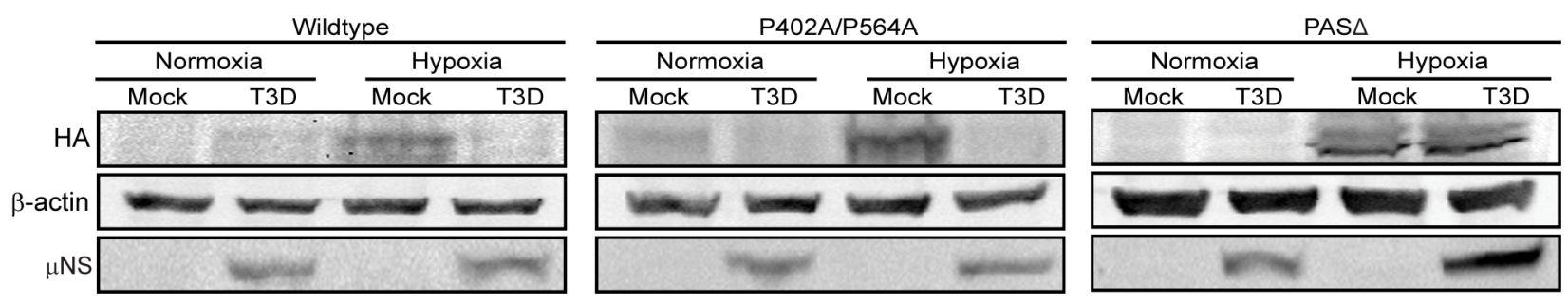

Figure 4: PAS domain region of $\mathrm{HIF}-1 \alpha$ is required for its MRV-induced down-regulation. PC-3 cells were transfected with pHA-HIF-1 $\alpha$, pHA-HIF-1 $\alpha$ P402A/P564A or pHA-HIF-1 $\alpha \Delta$ PAS and incubated under normoxic or hypoxic conditions. At 24 h posttransfection cells were mock infected or infected with MRV T3D and further incubated under normoxic or hypoxic conditions. At $12 \mathrm{~h}$ p.i., cells were harvested and proteins were separated on SDS-PAGE and transferred to nitrocellulose. Blots were immunostained with mouse $\alpha$-HA antibodies, rabbit $\alpha-\beta$-actin or rabbit $\alpha-\mu$ NS antiserum followed by AP-conjugated goat $\alpha$-rabbit or mouse secondary antibodies. 
less RACK1 protein relative to control siRNA treated cells (Fig. 5B). As expected, MRV induced the downregulation of HIF- $1 \alpha$ in control siRNA treated samples. In cells transfected with RACK1 siRNAs, at $12 \mathrm{~h}$ p.i., where we previously measured the greatest MRV impact on HIF$1 \alpha$ proteasome-mediated degradation, accumulation of HIF-1 $\alpha$ was nearly completely rescued (Fig. 5A). At 24 $\mathrm{h}$ p.i., there was also a substantial rescue of HIF-1 $\alpha$ in the MRV-infected RACK1 knockdown cells relative to control siRNA knockdown cells, however, complete rescue was not observed, likely as a result of the previously identified MRV-induced translational inhibition of HIF-1 $\alpha$ mRNA that is occurring by this time p.i. These results indicate that when RACK1 expression is diminished, MRV is unable to induce HIF-1 $\alpha$ downregulation. Taken together with data in Fig. 3-4, this strongly suggests that MRV infection induces ubiquitin-dependent, proteasome-mediated degradation of HIF-1 $\alpha$ via a RACK1-dependent pathway in hypoxic prostate tumor cells.

\section{MRV infection induces apoptotic cell death in hypoxic prostate tumor cells.}

Hypoxic cancer cells evade apoptosis by upregulating anti-apoptotic factors [39-41] and downregulating pro-apoptotic factors [42], while MRV infection induces apoptosis [43]. To determine if MRV infection surmounts the hypoxic anti-apoptosis response in PCa cells, we performed a number of experiments. Viability assays based on live-cell protease activity showed that MRV infection caused significantly reduced viability of both hypoxic and normoxic tumor cells relative to uninfected cells (Fig. 6A). Concurrent apoptosis assays showed increased caspase 3/7 activity in MRV infected hypoxic and normoxic tumor cells when compared to uninfected cells (Fig. 6B), suggesting MRV was killing hypoxic tumor cells via an apoptotic pathway. Additional examination of uninfected and infected cell lysates showed cleaved PARP, a hallmark of apoptosis, in MRV infected hypoxic and normoxic tumor cells but not in uninfected cells (Fig. 6C).

Apoptosis in cells occurs via intrinsic and extrinsic pathways. The intrinsic pathway involves the activation of caspase 9 and the extrinsic pathway leads to caspase 8 activation. MRV has been shown to induce apoptosis in normoxic cells in a tissue specific manner and has been shown to be both caspase 8 and 9 dependent [44]. In order to further illuminate the mechanism of MRV induced apoptosis in hypoxic prostate tumor cells, we determined the activation status of caspase 8 and caspase 9 in MRVinfected hypoxic DU145 cells. Paclitaxel, which induces
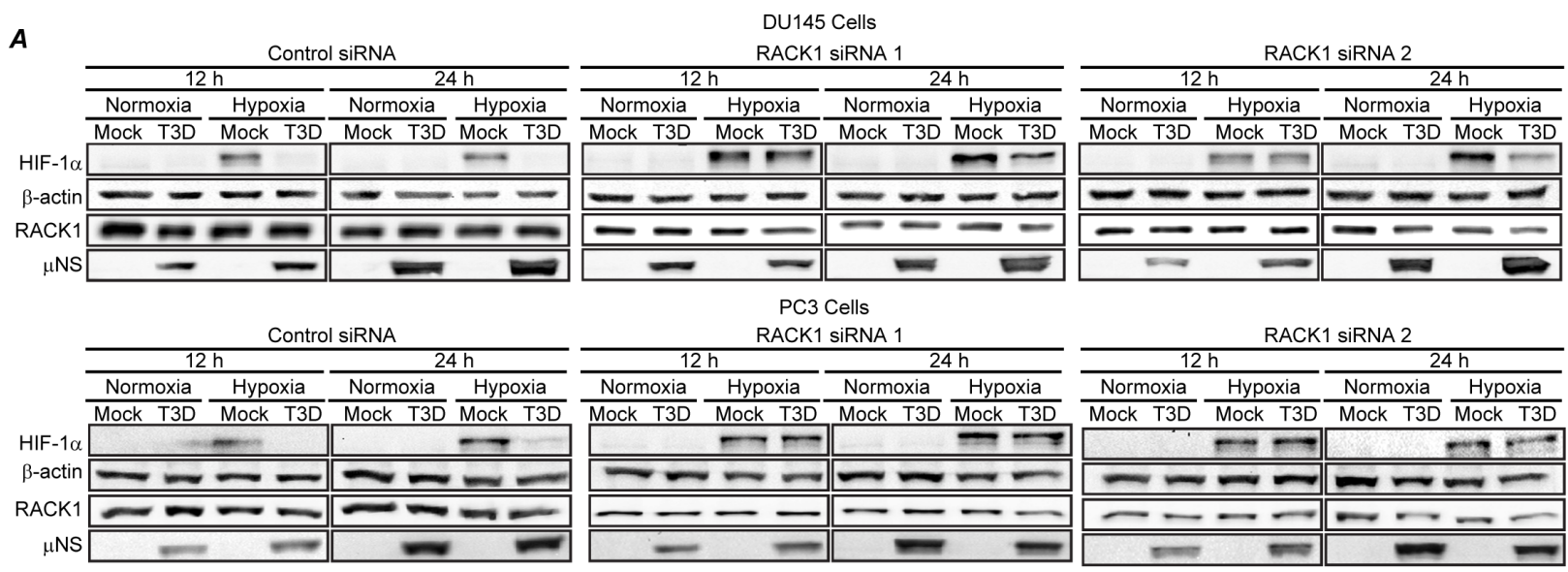

B
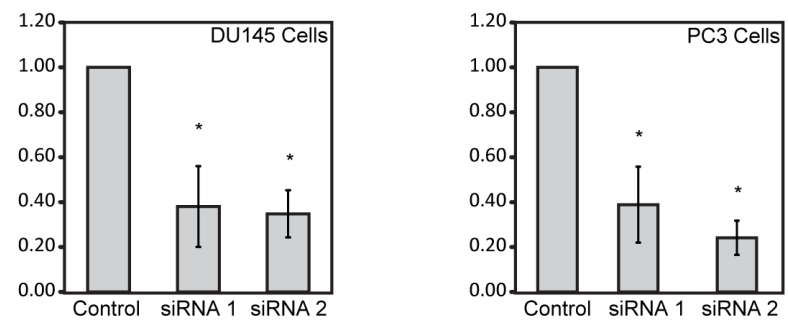

Figure 5: RACK1 knockdown by siRNAs prevents MRV-induced HIF-1 $\alpha$ degradation in hypoxic tumor cells. DU145 and PC-3 cells were transfected with control or RACK1-specific siRNAs and incubated under normoxic or hypoxic conditions. At 20 $\mathrm{h}$ post-transfection, cells were mock infected or infected with MRV T3D and further incubated under normoxic or hypoxic conditions. At $12 \mathrm{~h}$ and $24 \mathrm{~h}$ p.i., cells were harvested and proteins were separated on SDS-PAGE and transferred to nitrocellulose. A) Blots were immunostained with rabbit $\alpha-\mu$ NS antiserum, mouse $\alpha$-HIF- $1 \alpha$ antibodies, mouse $\alpha$-RACK 1 monoclonal antibodies or rabbit $\alpha-\beta$-actin antibodies followed by AP-conjugated goat $\alpha$-rabbit or mouse secondary antibodies. B) RACK1 knockdown by siRNA1 and siRNA2 was quantified by measuring the mean of all knockdown samples in each cell type relative to control samples and plotted on a graph. Error bars represent the standard deviation and statistically significant differences $(\mathrm{p}<0.05)$ are marked with '*'. 
apoptosis via activation of both caspase 8 and 9 was used as a positive control. Caspase activity was measured by Caspase 8/9 Glo assays at 24 and $48 \mathrm{~h}$ p.i. From these experiments, it was clear that MRV infection induced the activation of both caspases in normoxic and hypoxic prostate tumor cells (Fig. 6D). Taken together, these data show that MRV infection has the capacity to override the anti-apoptotic effects of hypoxia and induce cell death by activating both the intrinsic and extrinsic apoptosis pathways, ultimately resulting in death of hypoxic prostate tumor cells.

\section{DISCUSSION}

Low oxygen in prostate tumors is strongly predictive of relapse after therapy [45], illustrating the need to identify novel treatment strategies that target hypoxic tumor cells, and the HIF-1 $\alpha$ protein that modulates the cellular hypoxic response. In this study, we have identified
MRV as one such potential therapy by demonstrating that MRV replicates to high levels in prostate tumor cells grown in hypoxic environments (Fig. 1), induces massive downregulation of the HIF-1 $\alpha$ protein via degradation and translational inhibition (Figs. 2, 3), and leads to apoptosis of the cells (Fig. 6). It is important to note that our data does not suggest that MRV specifically targets hypoxic cells, merely that the ability of MRV to replicate and induce apoptosis of tumor cells can be expanded to include those growing in a hypoxic microenvironment. These findings illustrate that the cellular adaptations that occur during hypoxia are not detrimental to successful MRV replication. This natural ability to replicate in hypoxic cells is similar to that seen in vesicular stomatitis virus (VSV), which has previously been shown to replicate in hypoxic HeLa cells and in hypoxic regions of C6 gliobastoma tumor xenografts [46]. Like VSV, the natural ability of MRV to replicate in hypoxic tumor cells circumvents the need to alter the virus for specific replication in the
$\boldsymbol{A}$

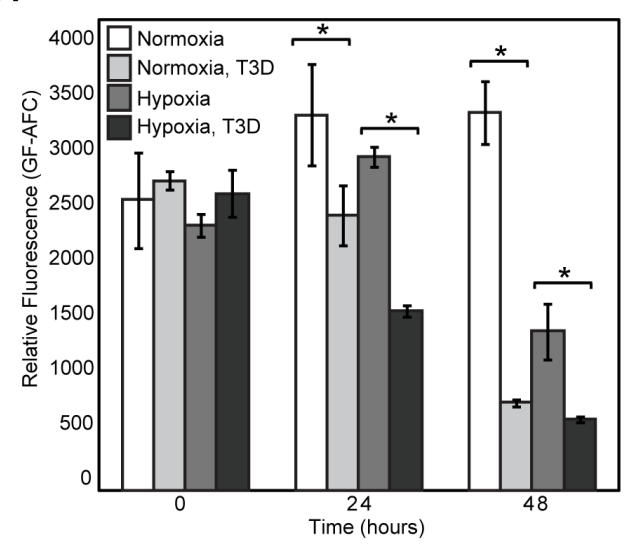

B

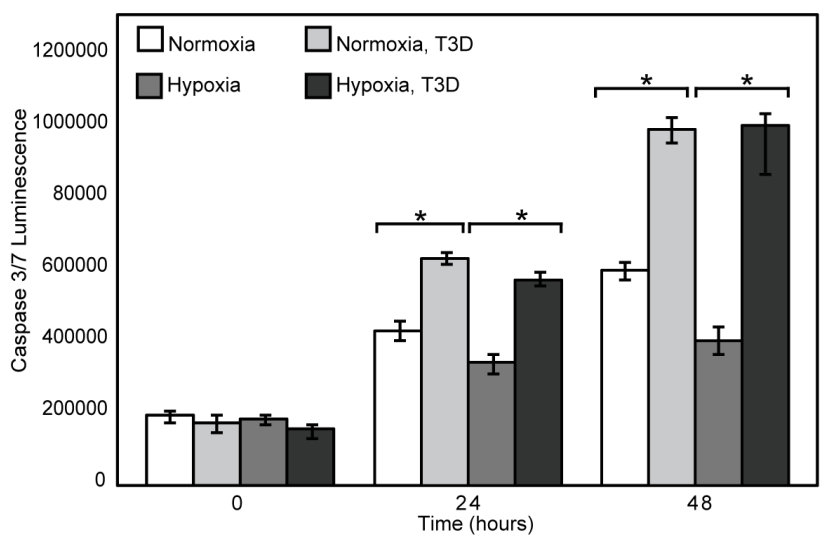

C
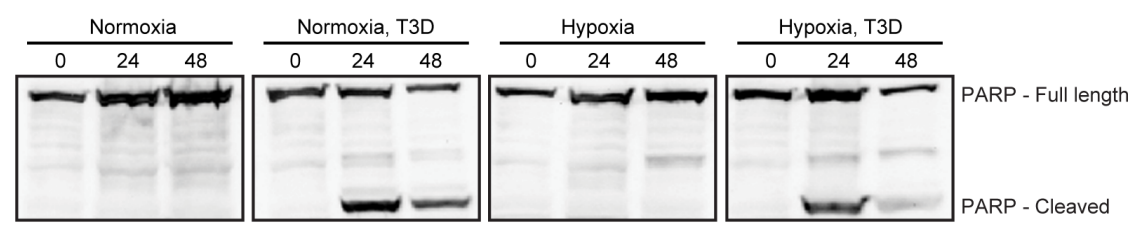

D
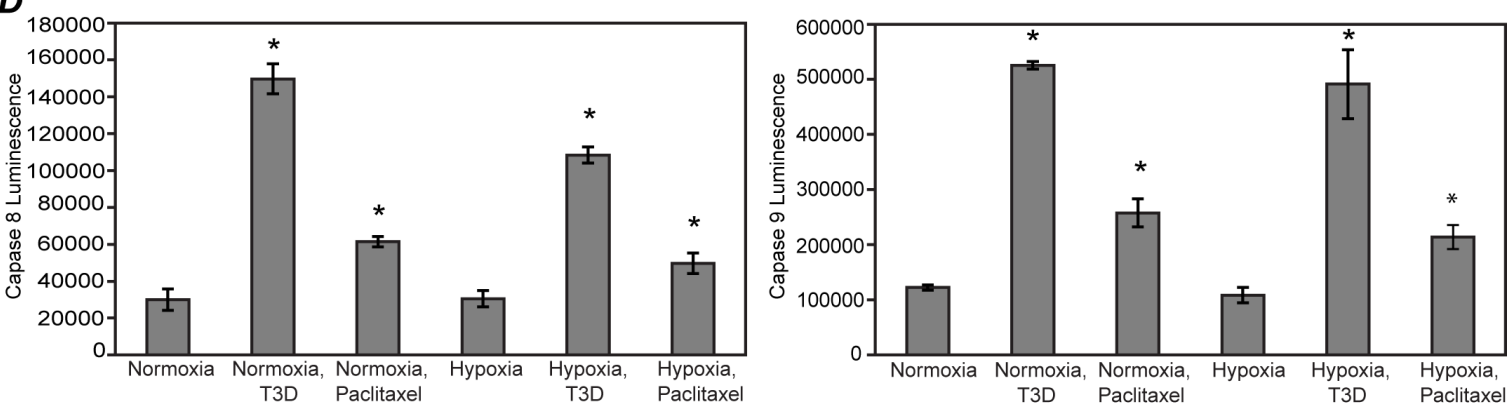

Figure 6: MRV kills hypoxic prostate tumor cells via apoptosis. Normoxic or hypoxic DU145 cells were mock-infected or infected with MRV T3D and further incubated in normoxic or hypoxic conditions. A) At 0, 24 and $48 \mathrm{~h}$ p.i., cells were subjected to viability assay. B) At 0, 24, and 48 hours, cells were lysed and caspase 3/7 activity was measured. Error bars represent SD of three experimental replicates. Statistically significant differences $(\mathrm{p}<0.05)$ are marked with '*'. C) At 0, 24, and 48 hours, cells were lysed, and immunoblotted with antibodies against PARP. D) At 24 h p.i., cells were lysed and caspase 8 or caspase 9 activities was measured. Error bars represent SD of three experimental replicates. Statistically significant differences $(\mathrm{p}<0.05)$ are marked with '*'. 
hypoxic microenvironment, as is being investigated in other promising oncolytic viruses [46-48].

The downregulation of HIF-1 $\alpha$ during MRV infection of $\mathrm{PCa}$ cells is mediated by proteasomemediated degradation, and translational inhibition (Fig. $3)$. It remains unclear if HIF- $1 \alpha$ degradation is a specific consequence of MRV infection, or occurs as a non-specific result of MRV impact on other proteins involved in HIF$1 \alpha$ regulation. One particularly attractive candidate HIF$1 \alpha$ regulatory protein is HSP90, which has been shown to be involved in folding of the MRV trimeric attachment protein $\sigma 1$ [49]. Usurpation of HSP90 in infected cells for $\sigma 1$ folding may indirectly lead to RACK1-mediated degradation of HIF- $1 \alpha$. Inhibition of HIF- $1 \alpha$ translation at later times in MRV infection may occur as a result of modification of the translational machinery during virus infection. MRV has been shown to induce translational shutoff in many cell types, although we have been unable to detect a similar general inhibition of translation by MRV in the prostate tumor cells used in these studies (Gupta-Saraf and Miller, unpublished). It is possible that sequestration of translation initiation factors by viral mRNA results in downregulation of HIF- $1 \alpha$ translation. Further elucidation of how MRV infection modifies the cellular translation machinery should shed light on how HIF- $1 \alpha$ mRNA translation is inhibited in infected cells.

The PAS domain of HIF-1 $\alpha$, which is required for RACK1 and HSP90 binding [50], is required for MRV-induced degradation (Fig. 4). Additionally, siRNA knockdown of RACK1 inhibits MRV-induced HIF-1 $\alpha$ degradation (Fig. 5). This suggests that MRV infection may result in modification of the interaction between RACK1 or HSP90 and HIF-1 $\alpha$. MRV infection may increase the RACK $1 / \mathrm{HIF}-1 \alpha$ interaction or interfere with the HSP90/HIF-1 $\alpha$ interaction, leading to increased HIF-1 $\alpha$ degradation. Moreover, post-translational modifications of both HSP90 (acetylation) and RACK1 (phosphorylation) play important roles in regulation of HIF- $1 \alpha$ association $[51,52]$ and it is possible that MRV infection alters these modifications. Finally, cellular modulators of interactions between HIF-1 $\alpha$, RACK1 and HSP90 that regulate HIF- $1 \alpha$ protein levels may also be altered by MRV infection. Potential examples of this are the mammalian septin family member, SEPT9_v1, which has been reported to bind HIF-1 $\alpha$ and prevent RACK1 mediated proteasome targeting [53] or the SSAT2 protein, which binds to HIF-1 $\alpha$ and RACK1 and promotes HIF$1 \alpha$ ubiquitination [54]. Elucidating these possibilities will be essential for gaining a full understanding of how MRV induces HIF- $1 \alpha$ degradation and is currently under investigation.

Hypoxia selects for cancer cells that can evade apoptosis [55]. We show that MRV can extend its oncolytic properties to hypoxic PCa cells via induction of apoptosis by activating both caspase 8 and 9 (Fig. 6). This suggests that MRV infection can override the anti- apoptotic pathways induced by hypoxia. Because HIF-1 $\alpha$ plays a role in inhibition of apoptosis in hypoxic cells, it is possible that MRV-induced downregulation of HIF- $1 \alpha$ allows cells to activate their normal apoptosis response to hypoxia in infected cells. The exact pathway of MRVinduced apoptosis in hypoxic prostate tumor cells is currently under investigation.

We show that MRV downregulates the attractive cancer therapeutic target HIF-1 $\alpha$ and induces apoptosis in hypoxic prostate tumor cells. These findings augment existing information regarding the capacity of MRV to infect different tumor cell types growing in diverse physiologically relevant microenvironments. Validation of MRV oncolytic therapy of $\mathrm{PCa}$ in clinical trials is ongoing and has been shown to have a positive effect on disease regression [29]. MRV has also been shown to work in synergism with chemotherapy drugs such as docetaxel, which is the first line chemotherapy for treatment of androgen resistant $\mathrm{PCa}$ [30]. Our study extends the potential value of MRV treatment in PCa to include hypoxic prostate tumor cells, and provides a rationale to pursue future in vivo animal studies investigating the efficacy of MRV against hypoxic microregions within PCa tumors either alone or in combination with other standard chemotherapy treatments that are not effective against hypoxic cells. As hypoxia is present throughout the course of PCa, our data further suggests that MRV therapy may also be a strong candidate for targeting hypoxic cells and HIF- $1 \alpha$ in PCa clinical trials.

\section{MATERIALS AND METHODS}

\section{Cells and reagents}

DU145 cells were maintained in Eagle's modified essential medium (Invitrogen), PC3 cells were maintained in $\mathrm{F}-12 \mathrm{~K}$ media, and $\mathrm{LNCaP}$ cells were maintained in RPMI media (ATCC), containing 10\% fetal bovine serum (Atlanta Biologicals) and penicillin-streptomycin (100 IU/ml, Mediatech). L929 cells were maintained in Joklik's minimal essential medium (Irvine Scientific) containing $2 \%$ bovine calf serum, $2 \%$ fetal bovine serum (Atlanta Biologicals), $2 \mathrm{mM}$ L-Glutamine (Mediatech) and penicillin-streptomycin (100 IU/ml, Mediatech). All cell lines were obtained from the American Type Culture Collection. Primary antibodies used were as follows: mouse monoclonal anti-RACK1 (BD Biosciences), mouse monoclonal anti-HIF-1 $\alpha$ (Becton, Dickinson and Company Biosciences), rabbit polyclonal anti- $\beta$-actin (Cell Signaling Technologies), rabbit monoclonal antiPARP (Cell Signaling Technologies), rabbit polyclonal anti- $\mu$ NS [56], and mouse anti-HA (Cell Signaling Technologies). Secondary antibodies used for immunoblot experiments were alkaline phosphatase (AP)-conjugated 
goat anti-mouse or anti-rabbit IgG (Bio-Rad). Secondary antibodies used in immunofluorescence experiments were Alexa 488-conjugated donkey anti-mouse, and Alexa 594-conjugated donkey anti-rabbit immunoglobulin $\mathrm{G}$ (IgG) antibodies (Invitrogen). Proteasome inhibitor, MG132 (Enzo Life Sciences), was used at a final concentration of $10 \mu \mathrm{M}$, cobalt chloride $\left(\mathrm{CoCl}_{2}\right)$ at a final concentration of $500 \mu \mathrm{M}$ and NSC 632839 hydrochloride (F6) (BostonBiochem) at a final concentration of $30 \mu \mathrm{M}$.

\section{Infection and Transfection}

MRV virions (T3D strain) are from our laboratory stocks. Purified virions were prepared as described [57], using Vertrel reagent (DuPont) in place of Freon, and stored in dialysis buffer $(150 \mathrm{mM} \mathrm{NaCl} ; 10 \mathrm{mM}$ Tris $\mathrm{pH}$ $7.4 ; 10 \mathrm{mM} \mathrm{MgCl}_{2}$ ) at $4{ }^{\circ} \mathrm{C}$. Cells were seeded onto 60 $\mathrm{mm}, 35-\mathrm{mm}$, or $9.6-\mathrm{cm}^{2}$ cell culture dishes $24 \mathrm{~h}$ before infection. Cells were infected with MRV virions at a cell infectious unit (CIU) of 1 based on titers determined on cell lines used as previously described [58].

\section{Hypoxia}

Hypoxic conditions were obtained by incubating cells in $1 \% \mathrm{O}_{2}$ and $5 \% \mathrm{CO}_{2}$ at $37^{\circ} \mathrm{C}$ in a Galaxy $48 \mathrm{R}$ $\mathrm{CO}_{2}$ Incubator (New Brunswick Scientific) equipped with $1-19 \% \mathrm{O}_{2}$ controls. For all experiments the cells were adapted to hypoxia for $4 \mathrm{~h}$ prior to infection.

\section{Immunoblotting}

Cells were lysed in $100 \mu \mathrm{L} 2 \mathrm{X}$ SDS protein loading buffer (125 mM Tris. $\mathrm{HCl}$ [pH 6.8], 200 $\mathrm{mM}$ DTT, 4\% SDS, 0.2\% Bromophenol blue, 20\% Glycerol). Immunoblots were performed as previously described [58]. Blots were exposed to Lumi-Phos ${ }^{\mathrm{TM}} \mathrm{WB}$ Chemiluminescent Substrate (Thermo Scientific), and images were collected and quantified using a ChemiDoc XRS camera and QuantityOne software (Bio-Rad). All experiments were independently performed at least 3 times and representative results are shown.

\section{Immunofluorescence}

Cells were fixed and processed for immunofluorescence as previously described [56]. Samples were imaged with a Zeiss Axiovert 200 inverted microscope equipped with fluorescence optics. Images were prepared using Photoshop and Illustrator software (Adobe Systems). All experiments were independently performed at least 3 times and representative results are shown.

\section{Virus Replication Assay}

Samples were harvested and subjected to 3 freeze thaw cycles. Serial ten-fold dilutions in phosphatebuffered saline (PBS) (137 mM NaCl, $3 \mathrm{mM} \mathrm{KCl,} 8 \mathrm{mM}$ $\left.\mathrm{Na}_{2} \mathrm{HPO}_{4}[\mathrm{pH} 7.5]\right)$ containing $2 \mathrm{mM} \mathrm{MgCl}$ were made and plaque forming units (PFU) were determined by standard plaque assay on L929 cells [59]. The experiment was done thrice independently and the average of the three experiments was plotted on a bar graph with error bars depicting the standard error of the averages.

\section{Quantitative Real-Time PCR}

RNA was harvested using Trizol (Invitrogen) as per manufacturer's instruction. $1 \mu \mathrm{g}$ RNA was treated with DNAase I (New England Biolabs) then used to make cDNA with Superscript III Reverse Transcriptase (Invitrogen) as per manufacture's protocol. Primers used were as follows: $\beta$-actin (409 bp), the forward primer was ACCAACTGGGACGACATGGAGAAA and the reverse primer was TTAATGTCACGCACGATTTCCCGC; HIF-1 $\alpha$ (564 bp), the forward primer was GAACCTGATGCTTTAACT and the reverse primer was CAACTGATCGAAGGAACG. The cDNA was amplified by qPCR using $0.1 \mu \mathrm{M}$ primers, $0.7 \mathrm{X}$ SYBR green, $200 \mu \mathrm{M}$ dNTP, 1X GoTaq Reaction Buffer, 1.25 $\mathrm{U}$ GoTAQ polymerase (Promega) and $2 \mu \mathrm{L}$ of reverse transcription reaction mixture as template in an Opticon cycler (Biorad). The $\mathrm{C}(\mathrm{t})$ value of HIF-1 $\alpha$ was averaged using the $C(t)$ value of $\beta$-actin and plotted on a graph. The experiment was done thrice independently and each experiment included 2 replicates. The average of the three experiments was plotted on a bar graph with error bars depicting the standard error of the averages.

\section{Transfection}

Commercially available control and RACK1 specific siRNAs (Cat. No. 4392421-s20342, s20341, Ambion) were complexed with Lipofectamine 2000 (Invitrogen) according to the manufacturer's protocol and added to cell suspension prepared by trypsinization in $1 \mathrm{~mL}$ of OptiMEM. After 4 hours incubation, $1 \mathrm{~mL}$ of Eagle's MEM with $20 \% \mathrm{FBS}$ and no antibiotics was added. After 24 $\mathrm{h}$ incubation at $37^{\circ} \mathrm{C}$, new siRNA:Lipofectamine 2000 complexes were prepared and added to the transfected adherent cells. Following a $24 \mathrm{~h}$ incubation in normoxic conditions, transfected cells were mock-infected or infected with MRV and incubated in either normoxic or hypoxic conditions for 12 or $24 \mathrm{~h}$, at which point cells were harvested and lysed in protein loading dye and subjected to immunoblot analysis. Blots were exposed to Lumi-Phos ${ }^{\mathrm{TM}}$ WB Chemiluminescent Substrate (Thermo 
Scientific), and images were collected and quantified using a ChemiDoc XRS camera and QuantityOne software (Bio-Rad). The experiment was repeated independently 3 times and representative results are shown. Plasmid transfection was performed using TransIT-LT1 (Mirus) as per manufacturer's protocol.

\section{Viability and caspase activity assay}

Cells were subjected to the ApoTox-Glo Triplex Assay (Promega) or Caspase 8/9 Glo Assay (Promega) according to the manufacturer's protocol. Fluorescence and luminescence was recorded using GloMax Multi+ microplate reader (Promega). Graphs were constructed using Microsoft Excel. Results shown are the average and standard deviation of three experimental replicates. Statistical significance was calculated using averages of 3 experimental replicates.

\section{Plasmid Construction}

A firefly luciferase reporter plasmid (pGL4.26 luc2/minP/Hygro) was purchased from Promega. Upper and lower oligonucleotides were designed which contain three copies of the hypoxia response element [60], 5' GTACGTGCT 3', flanked on each end by NheI and HindIII restriction sites (New England Biolabs). Oligonucleotides were annealed and ligated into NheI and HindIII digested pGL4.26 luc $2 / \mathrm{minP} /$ Hygro to create pHRE-Luc. pHA-HIF-1 $\alpha$ [Addgene plasmid 18949, [61]] and pHA-HIF-1 $\alpha$ P402A/P564A [Addgene plasmid 18955, [62]] were obtained from Dr. William G Kaelin, Addgene. pHA-HIF-1 $\alpha \Delta$ PAS was created by HindIII digestion of pHA-HIF-1 $\alpha$ to remove aa 85-298 containing the PAS domain. A synthetic double-stranded DNA flanked on the end with BamH1 and AgeI digestion sites and containing HIF-1 $\alpha$ nt 1-1096, with the PAS domain (nt 253-894) deleted was purchased (gBlock, Integrated DNA Technologies), digested with BamHI and AgeI, and ligated into the digested pHA-HIF-1 $\alpha$. Following ligation, transformation, and screening, all plasmids were verified by sequencing.

\section{Luciferase Assay}

Cells were transfected with pHRE-Luc using Lipofectamine 2000 (Invitrogen) according to the supplier's protocol. Luciferase expression was measured using the One-Glo Luciferase Assay Kit and the luminescence function of a GloMax Multi+ microplate reader (Promega). Following recording of luminescence, cells were lysed and total protein measured using Bradford Assay (Biorad) and the absorbance function of a GloMax Multi+ microplate reader. Luminescence levels were normalized to total protein and plotted on a graph. Results shown are means and standard deviation of three experimental replicates. The statistical significance was calculated using the average of 3 experimental replicates.

\section{L-Azidohomoalanine (L-AHA) protein labeling and precipitation}

$50 \mu \mathrm{M}$ L-AHA (Invitrogen) was added to cells at 6 or $18 \mathrm{~h}$ p.i. then cells were harvested in lysis buffer $(1 \%$ SDS in $50 \mathrm{mM}$ Tris-HCl, $\mathrm{pH} 8.0$ ) at $12 \mathrm{~h}$ or $24 \mathrm{~h}$ p.i., respectively. L-AHA-labeled proteins were conjugated with biotin as per manufacture's protocol. Following conjugation, proteins were precipitated and resuspended in $100 \mu \mathrm{L}$ lysis buffer, diluted to $800 \mu \mathrm{l}$ in Tris-buffered saline (20 mM Tris, $137 \mathrm{mM} \mathrm{NaCl}[\mathrm{pH} 7.6])$ containing $0.1 \%$ Tween (TBS-T) and incubated for $2-3 \mathrm{~h}$ at room temperature with streptavidin magnetic beads (Pierce) prepared as per manufacturer's instruction. Beads were collected and washed 6 times with TBS-T, then suspended in $2 \mathrm{X}$ SDS protein loading buffer for immunoblot analysis.

\section{Statistical Analysis}

Statistical significance was determined using student's t-test and two-tailed $p$ value calculated with GraphPad software. Differences in groups for which $\mathrm{p}<0.05$ were considered to be statistically significant and are indicated with an asterisk in the figures.

\section{CONFLICT OF INTEREST}

The authors declare no conflict of interest.

\section{ACKNOWLEDGEMENTS}

The authors thank Deepak Navi for technical assistance, and members of the Miller lab for helpful discussion on this project and manuscript. We also are grateful to Dr Marit Nilsen-Hamilton and Judhajeet Ray, Iowa State University, for technical assistance. This work was supported by a Roy J. Carver Charitable Trust Young Investigator grant, Margaret B. Barry Cancer Fund Research Award and NIH NIAID R15AI090635 to CLM. The funders had no role in study design, data collection and analysis, decision to publish, or preparation of the manuscript.

\section{Editorial note:}

This paper has been accepted based in part on peerreview conducted by another journal and the authors' response and revisions as well as expedited peer-review 
in Oncotarget.

\section{REFERENCES}

1. Semenza GL. Targeting HIF-1 for cancer therapy. Nat Rev Cancer. 2003; 3(10):721-732.

2. Dai T, Zheng H and Fu GS. Hypoxia confers protection against apoptosis via the PI3K/Akt pathway in endothelial progenitor cells. Acta Pharmacol Sin. 2008; 29(12):14251431.

3. Ghafar MA, Anastasiadis AG, Chen MW, Burchardt M, Olsson LE, Xie H, Benson MC and Buttyan R. Acute hypoxia increases the aggressive characteristics and survival properties of prostate cancer cells. The Prostate. 2003; 54(1):58-67.

4. Hockel M and Vaupel P. Biological consequences of tumor hypoxia. Semin Oncol. 2001; 28(2 Suppl 8):36-41.

5. Butterworth KT, McCarthy HO, Devlin A, Ming L, Robson T, McKeown SR and Worthington J. Hypoxia selects for androgen independent LNCaP cells with a more malignant geno- and phenotype. International journal of cancer Journal international du cancer. 2008; 123(4):760-768.

6. Rofstad EK. Microenvironment-induced cancer metastasis. Int J Radiat Biol. 2000; 76(5):589-605.

7. Subarsky P and Hill RP. The hypoxic tumour microenvironment and metastatic progression. Clin Exp Metastasis. 2003; 20(3):237-250.

8. Vaupel P, Kelleher DK and Hockel M. Oxygen status of malignant tumors: pathogenesis of hypoxia and significance for tumor therapy. Semin Oncol. 2001; 28(2 Suppl 8):29-35.

9. Brizel DM, Dodge RK, Clough RW and Dewhirst MW. Oxygenation of head and neck cancer: changes during radiotherapy and impact on treatment outcome. Radiother Oncol. 1999; 53(2):113-117.

10. Jemal A, Siegel R, Ward E, Hao Y, Xu J, Murray T and Thun MJ. Cancer statistics, 2008. CA Cancer J Clin. 2008; 58(2):71-96.

11. Talcott JA, Rieker P, Clark JA, Propert KJ, Weeks JC, Beard CJ, Wishnow KI, Kaplan I, Loughlin KR, Richie JP and Kantoff PW. Patient-reported symptoms after primary therapy for early prostate cancer: results of a prospective cohort study. J Clin Oncol. 1998; 16(1):275-283.

12. Chan N, Milosevic M and Bristow RG. Tumor hypoxia, DNA repair and prostate cancer progression: new targets and new therapies. Future Oncol. 2007; 3(3):329-341.

13. Milosevic M, Warde P, Menard C, Chung P, Toi A, Ishkanian A, McLean M, Pintilie M, Sykes J, Gospodarowicz M, Catton C, Hill RP and Bristow R. Tumor hypoxia predicts biochemical failure following radiotherapy for clinically localized prostate cancer. Clinical cancer research : an official journal of the American Association for Cancer Research. 2012; 18(7):2108-2114.

14. Wang GL, Jiang BH, Rue EA and Semenza GL. Hypoxiainducible factor 1 is a basic-helix-loop-helix-PAS heterodimer regulated by cellular O2 tension. Proc Natl Acad Sci U S A. 1995; 92(12):5510-5514.

15. Ivan M, Kondo K, Yang H, Kim W, Valiando J, Ohh M, Salic A, Asara JM, Lane WS and Kaelin WG, Jr. HIFalpha targeted for VHL-mediated destruction by proline hydroxylation: implications for $\mathrm{O} 2$ sensing. Science. 2001; 292(5516):464-468.

16. Jaakkola P, Mole DR, Tian YM, Wilson MI, Gielbert J, Gaskell SJ, Kriegsheim A, Hebestreit HF, Mukherji M, Schofield CJ, Maxwell PH, Pugh CW and Ratcliffe PJ. Targeting of HIF-alpha to the von Hippel-Lindau ubiquitylation complex by O2-regulated prolyl hydroxylation. Science. 2001; 292(5516):468-472.

17. Kamura T, Sato S, Iwai K, Czyzyk-Krzeska M, Conaway RC and Conaway JW. Activation of HIF1alpha ubiquitination by a reconstituted von Hippel-Lindau (VHL) tumor suppressor complex. Proc Natl Acad Sci U S A. 2000; 97(19):10430-10435.

18. Maxwell PH, Wiesener MS, Chang GW, Clifford SC, Vaux EC, Cockman ME, Wykoff CC, Pugh CW, Maher ER and Ratcliffe PJ. The tumour suppressor protein VHL targets hypoxia-inducible factors for oxygen-dependent proteolysis. Nature. 1999; 399(6733):271-275.

19. Salceda $\mathrm{S}$ and Caro J. Hypoxia-inducible factor 1alpha (HIF-1alpha) protein is rapidly degraded by the ubiquitinproteasome system under normoxic conditions. Its stabilization by hypoxia depends on redox-induced changes. J Biol Chem. 1997; 272(36):22642-22647.

20. Liu YV and Semenza GL. RACK1 vs. HSP90: competition for HIF-1 alpha degradation vs. stabilization. Cell Cycle. 2007; 6(6):656-659.

21. Norman KL and Lee PW. Reovirus as a novel oncolytic agent. J Clin Invest. 2000; 105(8):1035-1038.

22. Wilcox ME, Yang W, Senger D, Rewcastle NB, Morris DG, Brasher PM, Shi ZQ, Johnston RN, Nishikawa S, Lee PW and Forsyth PA. Reovirus as an oncolytic agent against experimental human malignant gliomas. J Natl Cancer Inst. 2001; 93(12):903-912.

23. Yang WQ, Lun X, Palmer CA, Wilcox ME, Muzik H, Shi ZQ, Dyck R, Coffey M, Thompson B, Hamilton M, Nishikawa SG, Brasher PM, Fonseca K, George D, Rewcastle NB, Johnston RN, et al. Efficacy and safety evaluation of human reovirus type 3 in immunocompetent animals: racine and nonhuman primates. Clin Cancer Res. 2004; 10(24):8561-8576.

24. Hingorani P, Zhang W, Lin J, Liu L, Guha C and Kolb EA. Systemic administration of reovirus (Reolysin) inhibits growth of human sarcoma xenografts. Cancer. 2011; 117(8):1764-1774.

25. Harrington KJ, Vile RG, Melcher A, Chester J and Pandha HS. Clinical trials with oncolytic reovirus: moving beyond phase I into combinations with standard therapeutics. Cytokine Growth Factor Rev. 2010; 21(2-3):91-98.

26. Comins C, Spicer J, Protheroe A, Roulstone V, Twigger K, 
White CM, Vile R, Melcher A, Coffey MC, Mettinger KL, Nuovo G, Cohn DE, Phelps M, Harrington KJ and Pandha HS. REO-10: a phase I study of intravenous reovirus and docetaxel in patients with advanced cancer. Clinical cancer research : an official journal of the American Association for Cancer Research. 2010; 16(22):5564-5572.

27. Alain T, Hirasawa K, Pon KJ, Nishikawa SG, Urbanski SJ, Auer Y, Luider J, Martin A, Johnston RN, JanowskaWieczorek A, Lee PW and Kossakowska AE. Reovirus therapy of lymphoid malignancies. Blood. 2002; 100(12):4146-4153.

28. Forsyth P, Roldan G, George D, Wallace C, Palmer CA, Morris D, Cairncross G, Matthews MV, Markert J, Gillespie Y, Coffey M, Thompson B and Hamilton M. A phase I trial of intratumoral administration of reovirus in patients with histologically confirmed recurrent malignant gliomas. Mol Ther. 2008; 16(3):627-632.

29. Thirukkumaran CM, Nodwell MJ, Hirasawa K, Shi ZQ, Diaz R, Luider J, Johnston RN, Forsyth PA, Magliocco AM, Lee P, Nishikawa S, Donnelly B, Coffey M, Trpkov K, Fonseca K, Spurrell J, et al. Oncolytic viral therapy for prostate cancer: efficacy of reovirus as a biological therapeutic. Cancer Res. 2010; 70(6):2435-2444.

30. Heinemann L, Simpson GR, Boxall A, Kottke T, Relph KL, Vile R, Melcher A, Prestwich R, Harrington KJ, Morgan R and Pandha HS. Synergistic effects of oncolytic reovirus and docetaxel chemotherapy in prostate cancer. BMC Cancer. 2011; 11:221.

31. Cho IR, Koh SS, Min HJ, Park EH, Ratakorn S, Jhun BH, Jeong SH, Yoo YH, Youn HD, Johnston RN and Chung YH. Down-regulation of HIF-1alpha by oncolytic reovirus infection independently of VHL and p53. Cancer Gene Ther. 2010; 17(5):365-372.

32. Figova K, Hrabeta $J$ and Eckschlager T. Anticancer efficiency of reovirus in normoxia and hypoxia. Folia biologica. 2013; 59(2):68-75.

33. Pipiya T, Sauthoff H, Huang YQ, Chang B, Cheng J, Heitner S, Chen S, Rom WN and Hay JG. Hypoxia reduces adenoviral replication in cancer cells by downregulation of viral protein expression. Gene Ther. 2005; 12(11):911-917.

34. Shen BH and Hermiston TW. Effect of hypoxia on Ad5 infection, transgene expression and replication. Gene Ther. 2005; 12(11):902-910.

35. Schmechel S, Chute M, Skinner P, Anderson R and Schiff L. Preferential translation of reovirus mRNA by a sigma3dependent mechanism. Virology. 1997; 232(1):62-73.

36. Epstein AC, Gleadle JM, McNeill LA, Hewitson KS, O'Rourke J, Mole DR, Mukherji M, Metzen E, Wilson MI, Dhanda A, Tian YM, Masson N, Hamilton DL, Jaakkola P, Barstead R, Hodgkin J, et al. C. elegans EGL-9 and mammalian homologs define a family of dioxygenases that regulate HIF by prolyl hydroxylation. Cell. 2001; 107(1):43-54.

37. Yee Koh M, Spivak-Kroizman TR and Powis G. HIF-1 regulation: not so easy come, easy go. Trends Biochem Sci. 2008; 33(11):526-534.

38. Aleo E, Henderson CJ, Fontanini A, Solazzo B and Brancolini C. Identification of new compounds that trigger apoptosome-independent caspase activation and apoptosis. Cancer research. 2006; 66(18):9235-9244.

39. Baek JH, Jang JE, Kang CM, Chung HY, Kim ND and Kim KW. Hypoxia-induced VEGF enhances tumor survivability via suppression of serum deprivation-induced apoptosis. Oncogene. 2000; 19(40):4621-4631.

40. Dong Z, Venkatachalam MA, Wang J, Patel Y, Saikumar P, Semenza GL, Force T and Nishiyama J. Up-regulation of apoptosis inhibitory protein IAP-2 by hypoxia. Hif-1-independent mechanisms. J Biol Chem. 2001; 276(22):18702-18709.

41. Gerber HP, Dixit V and Ferrara N. Vascular endothelial growth factor induces expression of the antiapoptotic proteins Bcl-2 and A1 in vascular endothelial cells. J Biol Chem. 1998; 273(21):13313-13316.

42. Erler JT, Cawthorne CJ, Williams KJ, Koritzinsky M, Wouters BG, Wilson C, Miller C, Demonacos C, Stratford IJ and Dive C. Hypoxia-mediated down-regulation of Bid and Bax in tumors occurs via hypoxia-inducible factor 1-dependent and -independent mechanisms and contributes to drug resistance. Mol Cell Biol. 2004; 24(7):2875-2889.

43. Clarke P, Richardson-Burns SM, DeBiasi RL and Tyler KL. Mechanisms of apoptosis during reovirus infection. Curr Top Microbiol Immunol. 2005; 289:1-24.

44. Clarke P, Debiasi RL, Goody R, Hoyt CC, RichardsonBurns S and Tyler KL. Mechanisms of reovirus-induced cell death and tissue injury: role of apoptosis and virusinduced perturbation of host-cell signaling and transcription factor activation. Viral Immunol. 2005; 18(1):89-115.

45. Marignol L, Coffey M, Lawler M and Hollywood D. Hypoxia in prostate cancer: a powerful shield against tumour destruction? Cancer Treat Rev. 2008; 34(4):313327.

46. Connor JH, Naczki C, Koumenis C and Lyles DS. Replication and cytopathic effect of oncolytic vesicular stomatitis virus in hypoxic tumor cells in vitro and in vivo. Journal of virology. 2004; 78(17):8960-8970.

47. Cuevas Y, Hernandez-Alcoceba R, Aragones J, NaranjoSuarez S, Castellanos MC, Esteban MA, Martin-Puig S, Landazuri MO and del Peso L. Specific oncolytic effect of a new hypoxia-inducible factor-dependent replicative adenovirus on von Hippel-Lindau-defective renal cell carcinomas. Cancer research. 2003; 63(20):6877-6884.

48. Friedman GK, Haas MC, Kelly VM, Markert JM, Gillespie GY and Cassady KA. Hypoxia Moderates gamma(1)34.5Deleted Herpes Simplex Virus Oncolytic Activity in Human Glioma Xenoline Primary Cultures. Transl Oncol. 2012; 5(3):200-207.

49. Gilmore R, Coffey MC and Lee PW. Active participation of Hsp90 in the biogenesis of the trimeric reovirus cell 
attachment protein sigma1. The Journal of biological chemistry. 1998; 273(24):15227-15233.

50. Liu YV, Baek JH, Zhang H, Diez R, Cole RN and Semenza GL. RACK1 competes with HSP90 for binding to HIF1alpha and is required for $\mathrm{O}(2)$-independent and HSP90 inhibitor-induced degradation of HIF-1alpha. Mol Cell. 2007; 25(2):207-217.

51. Liu YV, Hubbi ME, Pan F, McDonald KR, Mansharamani M, Cole RN, Liu JO and Semenza GL. Calcineurin promotes hypoxia-inducible factor 1alpha expression by dephosphorylating RACK1 and blocking RACK1 dimerization. J Biol Chem. 2007; 282(51):37064-37073.

52. Kong X, Lin Z, Liang D, Fath D, Sang N and Caro J. Histone deacetylase inhibitors induce VHL and ubiquitinindependent proteasomal degradation of hypoxia-inducible factor 1alpha. Molecular and cellular biology. 2006; 26(6):2019-2028.

53. Amir S, Wang R, Simons JW and Mabjeesh NJ. SEPT9 v1 up-regulates hypoxia-inducible factor 1 by preventing its RACK1-mediated degradation. J Biol Chem. 2009; 284(17):11142-11151.

54. Baek JH, Liu YV, McDonald KR, Wesley JB, Zhang $\mathrm{H}$ and Semenza GL. Spermidine/spermine N(1)acetyltransferase-1 binds to hypoxia-inducible factor-1alpha (HIF-1alpha) and RACK1 and promotes ubiquitination and degradation of HIF-1alpha. J Biol Chem. 2007; 282(46):33358-33366.

55. Graeber TG, Osmanian C, Jacks T, Housman DE, Koch CJ, Lowe SW and Giaccia AJ. Hypoxia-mediated selection of cells with diminished apoptotic potential in solid tumours. Nature. 1996; 379(6560):88-91.

56. Qin Q, Hastings C and Miller CL. Mammalian orthoreovirus particles induce and are recruited into stress granules at early times postinfection. J Virol. 2009; 83(21):1109011101 .

57. Mendez, II, Hermann LL, Hazelton PR and Coombs KM. A comparative analysis of freon substitutes in the purification of reovirus and calicivirus. J Virol Methods. 2000; 90(1):59-67.

58. Qin Q, Carroll K, Hastings C and Miller CL. Mammalian orthoreovirus escape from host translational shutoff correlates with stress granule disruption and is independent of eIF2alpha phosphorylation and PKR. J Virol. 2011; 85(17):8798-8810.

59. Furlong DB, Nibert ML and Fields BN. Sigma 1 protein of mammalian reoviruses extends from the surfaces of viral particles. J Virol. 1988; 62(1):246-256.

60. Mor I, Bruck T, Greenberg D, Berson A, Schreiber L, Grisaru D and Soreq H. Alternate AChE-R variants facilitate cellular metabolic activity and resistance to genotoxic stress through enolase and RACK1 interactions. Chem Biol Interact. 2008; 175(1-3):11-21.

61. Kondo K, Klco J, Nakamura E, Lechpammer M and Kaelin WG, Jr. Inhibition of HIF is necessary for tumor suppression by the von Hippel-Lindau protein. Cancer Cell. 2002; 1(3):237-246.

62. Yan Q, Bartz S, Mao M, Li L and Kaelin WG, Jr. The hypoxia-inducible factor 2 alpha $\mathrm{N}$-terminal and $\mathrm{C}$-terminal transactivation domains cooperate to promote renal tumorigenesis in vivo. Molecular and cellular biology. 2007; 27(6):2092-2102. 